\title{
Key problems of seismic zoning of urban areas adjacent to the Mongolia-Siberian region (by the example of Erdenet town)
}

\author{
V.I. Dzhurik ${ }^{1}$, T. Dugarmaa² , S.P. Serebrennikov ${ }^{1}$, Ts. Batsaikhan ${ }^{2}$ \\ ${ }^{1}$ Institute of the Earth's Crust SB RAS \\ ${ }^{2}$ Astronomy and Geophysics Center MAN
}

\begin{abstract}
The first approximation approach to seismic zoning of the areas adjacent to the Mongolia-Siberian region has been followed by the example of Erdenet town. The grounds have been given for problematic stages of working: study of some regular trends of seismic setting and current level of initial seismicity of the area; identification of seismic activity areas and assessment of their seismic potential; seismic modeling of sites with the most typical soil conditions; model theoretical calculating of basic parameters of seismic effects and model zoning of the investigated area. Technically, the stages of Erdenet town case study can serve as a basis for seismic zoning of the areas of interest that are adjacent to the Mongolia-Siberian region.

The work has been done under financial support of RFBR project No. 07-0590111.

\section{Introduction}

The study of regularities of current geodynamical processes, primarily of seismic, is one of the major tasks of joint research of the Institute of the Earth's Crust SB RAS and the Research Center of Astronomy and Geophysics MAS.

Over the course of the past century the Mongolia-Siberian region (southern areas of Siberia, western and central areas of Mongolia) witnessed the world's intercontinental earthquakes that are a direct evidence of its high seismic potential. On the other hand, a seismic hazard level defines largely the natural conditions for its development. Thus, the environment, its unique natural sites, future development, public safety and safety of civil and plant facilities are directly related to seismicity of the area [12]. In this regard, the study of extreme high seismicity of the region is very important. The study of this aspect is one of the "hottest" areas in current research, because the plans of development include large-scale actions that affect the interests of not only Russia and Mongolia but also of the world community. These are primarily the problems of ecological safety of the Baikal dependent in many ways on the situation in the Selenga basin. To this must be added a large framework of problems bound up with the development of major fields in the region, laying, hydraulic development of the Selenga River and, therefore, the urbanization
\end{abstract}


of the Selenga basin (rapidly developing towns and settlements: Ulaanbaatar, Erdenet, Darkhan, Kyakht, Gusinoozersk, Ulan-Ude, Selenginsk, and others).

An integrated geological-geophysical and seismological survey was made on the area at different times that allowed identifying seismic activity areas and assessing their seismic potential $[6,8]$. However, the region has not been adequately explored for a number of reasons, and some of its parts call for further investigation, detailing, and grounding. The joint research project is intended to study the regularities of current geodynamical processes, primarily of seismic setting. Much attention is given to the study of seismicity, extremely high in the region. An integrated geological-geophysical and seismological survey will be made to identify seismic activity areas and assess their seismic potential [6, 8]. It will cover the priority areas that call for further investigation of their seismic hazard, detailing, and grounding. These are vast areas of the Orkhon-Selenge and Dzhidino-Selenge interfluves. In the coming two years the survey will be concentrated precisely on these areas. The obtained materials will form a basis for unified technical approach to seismic zoning of the areas adjacent to the Mongolia-Siberian region. Presented below are the results of Erdenet town case study.

\section{Tectonics and seismic setting near Erdenet town}

One of problematic stages of assessing seismic hazard of the area near Erdenet town is the definition of its initial seismicity from the data on geological structure, tectonics, large earthquakes, potential earthquake source zones and their basic parameters, frequency, and others. The basis for seismic zoning of the area is the identification of seismogenic zones and grounding for their potential seismic hazard. With the results of earlier studies [1], we have presented three types of neotectonic structures with magnitude $>7.0$ (Fig. 1A): Orkhon-Tolsky tectonic fault system and Mogod and Bolnai faults [6]

The Orkhon-Tuul tectonic fault system combines the Orkhon and Tuul faults of the reverse-slip genetic type that vary from 70 to $100 \mathrm{~km}$ in extension. The structures are clearly documented by geological-geophysical methods. The Mogod fault, incorporated into the Tulet tectonic system, is documented by all identification methods. The Mogod earthquake produced a clearly defined continuous system of seismogenic faults extending for about $45 \mathrm{~km}$ [6]. The Bolnai fault within the investigated area is represented by the eastern fragment of large tectonic fault system of the same name, which is extending for $600 \mathrm{~km}$. The past and present tectonic activity has geological-geophysical and seismological support. Some smaller tectonic faults are defined near Erdenet town; they control regional morphostructural elements.

The investigated area is characterized by high seismic activity. A map of earthquake epicenters density has been plotted to provide a clear picture of seismicity of the area. The map shows seismic events recorded in recent years (Fig. 1B). 
High-seismicity zones located to the southwest and to the east of the town are best demonstrated by the map data.

Analysis of the map of epicenters provides support for a high seismic activity of the area, as seismic events have been recorded within all adjacent linear potential earthquake source zones. The largest of them (up to 16-energy class) are about $100 \mathrm{~km}$ to the southwest and $200 \mathrm{~km}$ to the northeast of the town. These earthquake shocks might be as large as 6-7 intensity units within the town [13].

The study of seismic hazard of the northern part of Mongolia made it possible to identify linear potential earthquake source zones (Fig. 1A). The Mogod potential earthquake source zone dominates the investigated area. Many earthquakes of low and mean energy level, recorded in the instrumental period (Fig. 1B), and the 1967 Mogod earthquake, one of the largest in the modern history of Mongolia, predetermined high seismic potential of this zone. For the most part, the Mogod seismic zone determines a general level of initial seismicity of Erdenet town.

The maximum magnitude of the earthquake recorded in the potential earthquake source zone is 7.8. On geophysical study of the Mogod fault, showed up in the 1967 earthquake, we found a tectonic structure parallel to traceable major fault at $70 \mathrm{~km}$ from it. The lack of any faulted surface and the similarity of velocity and subsurface electrical profiles to major tectonic structure (1967) suggested that in an earlier (pre-instrumental) period the Mogod fault zone experienced an earthquake equal to the 1967 earthquake in intensity [5]. The assumed magnitude for the zone is 7.9.

To the north of Erdenet town are the Busin gol, Kizhin and Chikoi potential earthquake source zones. These zones are the eastern fragment of high-seismicity sub-latitudinal area. Besides the fragments of the presented potential earthquake source zones, the area includes the Dzunnur and Bolnai zones with the highest seismic potential. The Busin gol zone on the investigated area is represented by its western part, lower active in terms of seismic (Fig. 1A). The eastern flank is of higher seismic activity. The occurrence of two large earthquakes and paleoseismic dislocation (Busin gol $-M=7.2$ ) permitted equating the potential earthquake magnitude to 7.5. The investigated area is bounded by the Orkhon-Tuul potential earthquake source zone on the southeast. The epicenters of earthquakes from 12energy class are recorded within the zone. The potential earthquake magnitude may run as high as 6.0-7.5.

We characterize seismic setting of the area adjacent to Erdenet town by the example of recurrence curve for the Orkhon-Tuul part of North Mongolia. Three curves were plotted earlier [6]; first two curves 1 and 2 (see Fig. 2A) were plotted with regard to the Mogod earthquake in 1964-1968. Curve 2 was plotted from the data on seismic events with 9-16 energy classes and curve 3 - from the data on small earthquakes (9-13 energy classes). As illustrated, the levels and slopes of the curves are in line. Curve 1 is plotted from the data on later seismic observations. 
Here the level and slope of the curve are close to the average values throughout Mongolia.

The average annual velocity (density) $\mathbf{V}_{\mathrm{M}}$ of the flow of seismic events of varying magnitudes $(\mathbf{M})$ for the Altai-Sayan-Baikal region including the whole of the Orkhon-Tolsly area [7] shows that this area may experience 10 earthquakes with $M=4.5$ once a year, 1 earthquake with $M=5.5$ once a year, 1 earthquake with $M=7$ every 10 years, and 1 earthquake with $M=8$ every 100 years (Table 1 ).

Mean recurrence of earthquakes of varying magnitudes for the

Altai-Sayan-Baikal region ( $d$ - days, $m$ - months, the rest - years).

\begin{tabular}{|c|c|c|}
\hline $\begin{array}{c}\text { Magnitude } \\
(\mathrm{M})\end{array}$ & $\begin{array}{c}\text { Intensity } \\
\left(\mathrm{I}_{0}\right)\end{array}$ & $\begin{array}{c}\text { Period } \\
\left(\mathrm{T}_{\mathrm{M}}\right)\end{array}$ \\
\hline 4 & V-VI & $14-15 \mathrm{~d}$ \\
\hline 4.5 & VI-VII & $1-2 \mathrm{~m}$ \\
\hline 5 & VII-VIII & $4 \mathrm{~m}$ \\
\hline 5.5 & VIII & 3 \\
\hline 6 & VIII-IX & 5 \\
\hline 6.5 & IX & 10 \\
\hline 7 & IX-X & 30 \\
\hline 7.5 & $\mathrm{X}$ & 100 \\
\hline 8 & $\mathrm{X}-\mathrm{XI}$ & 500 \\
\hline 8.5 & $>\mathrm{XI}$ & \\
\hline
\end{tabular}

The analysis of the earthquakes instrumentally recorded over the period from 1968 to 2002 also counts in favor of high seismic activity of the investigated area. 855 earthquakes of 8-energy class and about 300 earthquakes of 9-14 energy classes were recorded in this period within a radius of $120 \mathrm{~km}$ from Erdenet town; four of which were 7-unit intensity earthquakes and one had 8-unit intensity (Table 2). Earthquake intensity is given with regard to depths of focuses in the range of 10 $-20 \mathrm{~km}$ according to the equation [6]. 
Table 2

Number of seismic events

The recurrence curves for the same period (Fig. 2C, D) are rather easily approximated by linear relationship with slopes 0.48 and 0.4 . The slope of the first curve (Fig. 2C) shows the most effect of aftershocks of the Mogod earthquake. The second curve slope (Fig. 2D) shows somewhat less effect but a smaller amount of data for statistical processing (due to a wider spread of points).

For better understanding of seismic setting near Erdenet town, it is necessary

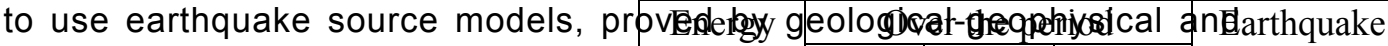

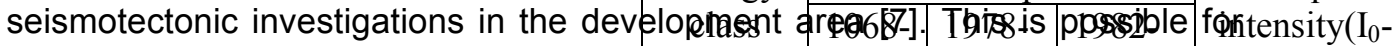
Erdenet town with the derivation of the seisknic settime eqeroirn. E00do this, units) recurrence intervals $T_{i}$ are determined corresponding to seismic eyents $l_{i}$ and then, using the obtained number pairs $\left(\mathrm{I}_{\mathrm{i}} \mathrm{T}_{\mathrm{i}}\right)$ and mathematigas devigas of progessing, determined are the coefficients of the equationof corretatjon of 1 ggarithmig type: 2.9

$$
\mathrm{I}_{\mathrm{T}}=\mathrm{a}+\mathrm{blg} \mathrm{T}
$$

\begin{tabular}{|c|c|c|c|}
\hline 10 & 78 & 25 & 22 \\
\hline 11 & $261)$ & 7 & 5 \\
\hline 12 & 7 & 5 & 5 \\
\hline
\end{tabular}

Magnitude (M)

where $a$ and $b$ are empirical coefficients of the seismic setting equation, 5 is whe earthquakes area

With the equation (1) one can improve earthquake intensity I corresponding to the assigned mean time $T=500,1000$ or 5000 years between the shocks of varying intensity. Probability $\mathbf{P}$ of exceedance of intensity $I_{T}$ during $\mathbf{t}$ years (i.e., if only one such event occurs) is determined by the equation known from [7]:

$$
\mathrm{P}=1-\mathrm{e}^{-\mathrm{t} / \mathrm{T}} .
$$

As is evident from the map of seismic zoning [6], an initial seismicity of Erdenet town is estimated at 8 units with index 2 . What this means is the town area 
will experience an 8-unit intensity shock every 1000 years. Although the estimation is of preliminary character, with the equation (2) we can determine probability $\mathbf{P}$ of exceedance of intensity $I_{T}$ at $T=1000$ years during $t=50$ years (i.e., if only one such event occurs) [7]. We obtain probability $\mathrm{P}$ of exceedance of intensity $\mathrm{I}_{\mathrm{T}}$ estimated at $5 \%$; it corresponds to acceptable risk in amount of $95 \%$ of nonexceedance probability during the same 50 years.

It seems plausible that the predicted intensity of the earthquake expected in the certain period of years for Erdenet town can be improved in the light of the statistical data available (see above). Nevertheless, the obtained values may be subject to improvement in longer-range studies of seismic setting or by mathematic modeling of predicted seismicity [17]. This is one of problems for the investigated area.

\section{Seismic properties of basic soils of the area of Erdenet town}

Seismic zoning on the area of the town requires the data on quantitative assessment of the parameters of ground motions in case of large earthquakes. These are primarily seismic hazard in intensity units, peak accelerations of ground motions, dominant period of motions in case of a large earthquake, and resonance frequencies of an unconsolidated unit. The parameter generation, in turn, requires setting of original seismic signals with regard to potential earthquake source zones and source parameters, seismic modeling in the right quantities, and performing theoretical calculations. The initial data for solving the posed problems have been obtained by seismogeological investigations and instrumental measurements made via shallow exploration on the area of the town. For this purpose, electrical, seismic and seismometric measurements have been made on the area of the town and sounding, seismic sounding and the earlier integrated data on seismic wave velocities were used $[4,13]$.

Within the town and industrial area there are rather solid intrusive and volcanogenic formations. The overall areal distribution of engineering-geological complexes is subject to main topographic features (eluvial and deluvial formations). Most of proluvial and alluvial deposits are confined to the segments of relatively old and recent stream flows or main drainage system of the area. Ground waters are associated with the Quaternary deposits. The depth of their occurrence is $0-2$ $m$ within the low flood plain, 2-6 $m$ within the second bottom, 4-10 $m$ within the first terrace, and about 15 and more meters on gentle slopes.

The geophysical measurement results are presented in the form of geoelectric section and seismic wave velocity structures in various soils (Fig. 3). The measurement technique is detailed in [2, 3, 15]. Electrical measurements have been made by VES survey [18] to determine hydrogeological and engineeringgeological building conditions within the low flood plain and the first terrace. Seismically these are the most hazardous parts. Seismic measurements have 
been made by refraction survey in design ( $Z Z$ and $Y Y$ ) via single soundings [14]. We suggest that seismic sounding points have been chosen with regard to equal coverage of soil conditions typical of the area of the town.

Geoelectric section extending for about $2 \mathrm{~km}$, obtained at the part between the town and industrial base at about $100 \mathrm{~km}$ from the automobile road, is descriptive of the distribution of layers with various apparent resistivity values $\left(\tilde{n}_{a}\right)$ with depth. At this part, the layers with lower $\tilde{n}_{a}$ have high porosity and rather high moisture content. The lower reference horizon has been recognized along curve " $\mathrm{H}$ " or its finite branch. It has relatively low resistivity values as compared with bedrock and can be attributed to high-fractured and water-saturated rocks. The upper layer at a depth of 30-40 m has the minimum resistivity values $\left(25-50 \mathrm{Ohm}^{*} \mathrm{~m}\right)$ typical of water-saturated loose grounds. The uppermost layer to a depth of 5-6 $\mathrm{m}$ corresponds to loose grounds $(100-200 \mathrm{Ohm} * \mathrm{~m})$. The anomalous resistivity parts in the lower layer are recognized in the points of curves 9-10 and 12-13; they are attributed to high-fracturing parts or to the parts of high-salinity ground waters.

For all seismic sounding points, the velocities are given in the form of histograms for air-seasoned and water-saturated loose and solid rocks (Fig. 3, II). The minimum values $V_{\text {p }}$ typical for the layer of seasonal freezing are ranging from 300 to $400 \mathrm{~m} / \mathrm{s}$ (Fig. $3 \AA$ ). The air-seasoned loose grounds are combined in one group without regard to the texture; the velocity range is from 500 to $1200 \mathrm{~m} / \mathrm{s}$ (Fig. 3B). The loose ground layer thickness is variable from 5-10 to 30 and more meters. The distribution maximums fall on velocity intervals $600-700 \mathrm{~m} / \mathrm{s}$ and $1000-1100$ $\mathrm{m} / \mathrm{s}$. The first one presumably corresponds to loose deposits dominated by relatively small fraction, and the second fits into coarsely clastic and disintegrated solid rocks. According to the norms existing $[9,10,16]$, the soils no less than $10 \mathrm{~m}$ in thickness, corresponding to the first distribution, belong to average in seismic properties (category II), and their seismic hazard will correspond to the initial one [11].

The velocity of longitudinal waves in the water-saturated loose grounds may be 2-5 times that in the air-seasoned. Velocity values $V_{p}$ are ranging from 1500 to $2300 \mathrm{~m} / \mathrm{s}$. In seismic properties, most of the loose soils fall in category III and their seismic hazard may increase one unit relative to the average soils [10].

According to the data available for the area Erdenet town [13], P-wave velocities vary with the degree of rock disintegration, from $700 \mathrm{~m} / \mathrm{s}$ in marls to 2000 $\mathrm{m} / \mathrm{s}$ in badly disintegrated rocks and from 2000 to 4000 in slightly disintegrated. In our case, the velocity range makes from 1200 to $3600 \mathrm{~m} / \mathrm{s}$ from disintegrated to low-fractured rocks (Fig. 3D). In seismic properties, these grounds fall into category I and their seismic hazard is typically taken as one unit less than the initial. The above velocities are, in this instance, taken as reference values, but this is largely true for the first maximum of their distribution.

We suggest seismic hazard of the area of the town will be zoned by seismic modeling of the sites with typical soil and building conditions. The first approximation 
models have been constructed from the engineering-geological data and seismic measurements made on these sites. Texture and conditions of soil, layer thickness $(h)$, velocities of longitudinal $\left(V_{p}\right)$ and transverse $\left(V_{s}\right)$ waves, density of soils $(\rho)$ and absorption decrements (д) are summarized in Table 3.

Table 3.

Parameters of computed seismic models for generalized typical sections

\begin{tabular}{|c|c|c|c|c|c|c|}
\hline $\begin{array}{l}\text { Model } \\
\text { No. }\end{array}$ & Soil conditions & $\begin{array}{c}\mathrm{h} \\
(\mathrm{m})\end{array}$ & $\begin{array}{c}\mathrm{V}_{\mathrm{p}} \\
(\mathrm{m} / \mathrm{s})\end{array}$ & $\begin{array}{c}\mathrm{V}_{\mathrm{s}} \\
(\mathrm{m} / \mathrm{s})\end{array}$ & $\begin{array}{c}\rho \\
\left(\mathrm{t} / \mathrm{m}^{3}\right)\end{array}$ & $\delta$ \\
\hline 1 & 2 & 3 & 4 & 5 & 6 & 7 \\
\hline 1 & $\begin{array}{c}\text { Solid rock } \\
\text { (reference model) }\end{array}$ & 10 & $\begin{array}{l}2400 \\
3000\end{array}$ & $\begin{array}{l}1300 \\
1600\end{array}$ & $\begin{array}{l}2.5 \\
2.6\end{array}$ & $\begin{array}{c}0,05 \\
0,045\end{array}$ \\
\hline 2 & $\begin{array}{l}\text { Landwaste with } \\
\text { sandy-loam filler. }\end{array}$ & $\begin{array}{c}5 \\
10\end{array}$ & $\begin{array}{c}500 \\
2400 \\
3000\end{array}$ & $\begin{array}{c}250 \\
1300 \\
1600\end{array}$ & $\begin{array}{l}1.8 \\
2.5 \\
2.6\end{array}$ & $\begin{array}{l}0,21 \\
0,05 \\
0,04\end{array}$ \\
\hline 3 & $\begin{array}{l}\text { Loess-like loam, } \\
\text { semigravel. }\end{array}$ & $\begin{array}{l}4 \\
6\end{array}$ & $\begin{array}{c}500 \\
600 \\
2400 \\
3000 \\
\end{array}$ & $\begin{array}{c}250 \\
300 \\
1300 \\
1600 \\
\end{array}$ & $\begin{array}{l}1.8 \\
1.9 \\
2.5 \\
2.6 \\
\end{array}$ & $\begin{array}{c}0,21 \\
0,2 \\
0,05 \\
0,04 \\
\end{array}$ \\
\hline 4 & $\begin{array}{l}\text { Loam, } \\
\text { landwaste. }\end{array}$ & $\begin{array}{l}3 \\
9\end{array}$ & $\begin{array}{c}500 \\
800 \\
2400 \\
3000\end{array}$ & $\begin{array}{c}250 \\
400 \\
1300 \\
1600\end{array}$ & $\begin{array}{l}1.8 \\
1.9 \\
2.5 \\
2.6\end{array}$ & $\begin{array}{l}0,21 \\
0,19 \\
0,05 \\
0,04\end{array}$ \\
\hline 5 & $\begin{array}{c}\text { Sand, loam, rock } \\
\text { debris, clumpy rock } \\
\text { debris. }\end{array}$ & $\begin{array}{l}9 \\
9\end{array}$ & $\begin{array}{c}700 \\
800 \\
2400 \\
3000 \\
\end{array}$ & $\begin{array}{c}350 \\
400 \\
1300 \\
1600\end{array}$ & $\begin{array}{l}1.9 \\
2.0 \\
2.5 \\
2.6\end{array}$ & $\begin{array}{c}0,2 \\
0,19 \\
0,05 \\
0,04\end{array}$ \\
\hline 6 & $\begin{array}{l}\text { Sands, loams. } \\
\text { Landwaste and } \\
\text { macrofragmental } \\
\text { soil. }\end{array}$ & $\begin{array}{l}10 \\
20 \\
20 \\
10\end{array}$ & $\begin{array}{c}700 \\
800 \\
900 \\
2400 \\
3000\end{array}$ & $\begin{array}{c}350 \\
350 \\
400 \\
1300 \\
1600\end{array}$ & $\begin{array}{l}1.8 \\
1.9 \\
2.0 \\
2.5 \\
2.6\end{array}$ & $\begin{array}{c}0,2 \\
0,19 \\
0,18 \\
0,05 \\
0,04\end{array}$ \\
\hline 7 & Average soils. & $\begin{array}{l}10 \\
10\end{array}$ & $\begin{array}{l}720 \\
2400 \\
3000\end{array}$ & $\begin{array}{c}360 \\
1300 \\
1600\end{array}$ & $\begin{array}{l}1.9 \\
2.5 \\
2.6\end{array}$ & $\begin{array}{c}0,2 \\
0,05 \\
0,04\end{array}$ \\
\hline 8 & $\begin{array}{c}\text { Unconsolidated, } \\
\text { water plane from } 5 \\
\mathrm{~m} .\end{array}$ & $\begin{array}{c}5 \\
5 \\
10\end{array}$ & $\begin{array}{c}720 \\
1600 \\
2400 \\
3000\end{array}$ & $\begin{array}{c}360 \\
380 \\
1300 \\
1600\end{array}$ & $\begin{array}{l}1.9 \\
2.0 \\
2.5 \\
2.6\end{array}$ & $\begin{array}{c}0,2 \\
0,18 \\
0,05 \\
0,04\end{array}$ \\
\hline 9 & $\begin{array}{c}\text { Unconsolidated, } \\
\text { water plane from } 3 \\
\mathrm{~m} .\end{array}$ & $\begin{array}{c}3 \\
7 \\
10\end{array}$ & $\begin{array}{c}720 \\
1600 \\
2400 \\
3000\end{array}$ & $\begin{array}{c}360 \\
380 \\
1300 \\
1600\end{array}$ & $\begin{array}{l}1.8 \\
2.0 \\
2.5 \\
2.6\end{array}$ & $\begin{array}{c}0,2 \\
0,18 \\
0,05 \\
0,04\end{array}$ \\
\hline 10 & $\begin{array}{l}\text { Medium soils, } \\
\text { flooded. }\end{array}$ & $\begin{array}{l}10 \\
10\end{array}$ & $\begin{array}{l}1700 \\
2400 \\
3000\end{array}$ & $\begin{array}{c}420 \\
1300 \\
1600\end{array}$ & $\begin{array}{l}2.0 \\
2.5 \\
2.6\end{array}$ & $\begin{array}{l}\mathbf{0 , 1 7} \\
\mathbf{0 , 0 5} \\
\mathbf{0 , 0 4}\end{array}$ \\
\hline
\end{tabular}


The authors point out that each of the models is constructed for a particular site of the town, and if it is uniform in velocity, one may restrict the constructing to one or several models. However, the site of irregular area and depth permits almost limitless number of models. If several uniform sites may represent the investigated area, the minimum of the models will correspond to the number of these sites. Generally, the number of models for the investigated area is determined by simulation error and an acceptable error of duplex soils in large building [2].

Models No. 1 and No. 7 correspond to reference rocks and moderately firm soils; they are more or less proved at the analysis of seismic properties of "moderately" firm and solid rocks. Models No. 2-6 correspond to water-unsaturated loose grounds that vary in thickness from 5 to $40 \mathrm{~m}$. They overlie solid rocks with "reference" velocity values. Three models, No. 8-10, have been constructed for the sites that vary in depth of occurrence of ground waters. The depth of occurrence of water plane makes 0,3 and $5 \mathrm{~m}$ respectively. Model No. 10 is completely on a par with model No. 7 in texture and thickness of loose soils.

For the models of particular parts of the town the calculation of seismic intensity has been made in units with regard to soil conditions and depth of occurrence of water plane by the procedure described in $[9,10]$. As a result, the calculations show that seismic intensity increments due to soil conditions vary from 0.96 to 2 units relative to "reference" solid rocks. If initial seismicity of the area of the town is set equal to 8 units (for average soils), seismic intensity of the sites represented by soil models (see Table 3 ) will vary from 7.96 to 9 units.

\section{Quantitative assessment of the parameters of seismic risk in case of large earthquakes for the area of Erdenet town}

When mapping or assessing seismic risk, the probability that an earthquake with intensity exceeding the predicted value will occur in the locality in a certain period (usually 50 or 100 years) is expressed for single construction works. An intensity characteristic in earthquake engineering practice is soil acceleration; it is expressed in terms of effective peak acceleration. This is predicted maximum acceleration for particular parts of the town represented by seismic models. Since this value is calculated for specific probability, it implies an uncertainty of destructive earthquake expected for the investigated area. At current investigations (see previous sections), the guide values of accelerations given below reflect $5-\%$ probability of exceedance or $95-\%$ probability of nonexceedance for the 50 -year seismic intensity values.

Thus, there is a need to calculate basic parameters that determine seismic intensity: accelerograms, spectral characteristic and acceleration spectra, i.e. the effect parameters used directly in seismic structural engineering. They are calculated for large earthquakes fitting the level of initial seismicity of the area. Although the 
calculation technique is under development, the calculation level (peak accelerations) is not variable.

Procedure [3, 4] and program [9] set has been used in calculating. The calculations need computed modeling and an original signal setting. The basic seismological data have been briefly analyzed and described above. The first approximation analysis shows the ranges in which large earthquake parameters are variable for the identified potential earthquake source zones (Fig. 1). They have the following intervals: epicenteral distance $0-100 \mathrm{~m}$, magnitude $6.0-7.9$, intensity 8 units, depth of focuses $10-20 \mathrm{~km}$, and focal mechanism - strike-slip and reverse slip.

Considering large earthquake parameters and variation ranges for the investigated area, we have synthesized an initial accelerogram for horizontal (EW) component by the earlier procedure [9]. The accelerogram is adjusted to rock foundation (Fig. 4); its basic parameters are as follows: peak acceleration $58 \mathrm{~cm} /$ $\mathrm{s}^{2}$, maximum spectrum value $10 \mathrm{~cm} / \mathrm{s}$, spectrum frequency interval at level 0.7 of the maximum varying from 1 to $5 \mathrm{~Hz}$, motion time at level 0.3 of the maximum being $20 \mathrm{~s}$.

Calculation of the acceleration on the solid rock surface for reference model No. 1 offers seismic motions at a twofold rate; essentially, it is due to double reflection. The emergent angle is set equal to $30^{\circ}$ from the vertical. The basic design parameters are summarized in Table 4.

Table 4

Parameters of design accelerograms and spectra for models No. 1-10.

\begin{tabular}{|c|c|c|c|c|c|}
\hline $\begin{array}{c}\text { Model No., } \\
\text { typical } \\
\text { section. }\end{array}$ & $\begin{array}{c}\text { acceleration } \\
\text { Ämax, } \\
\left(\mathrm{cm} / \mathrm{s}^{2}\right)\end{array}$ & $\begin{array}{c}\text { Maximum of } \\
\text { the spectrum } \\
(\mathrm{cm} / \mathrm{s})\end{array}$ & $\begin{array}{c}\text { Frequency of } \\
\text { major } \\
\text { maximum of } \\
\text { the spectrum } \\
(\mathrm{Hz})\end{array}$ & $\begin{array}{c}\text { Resonance } \\
\text { frequency of } \\
\text { loose layers } \\
(\mathrm{Hz})\end{array}$ & $\begin{array}{c}\text { Maximum } \\
\text { increasing at } \\
\text { resonance } \\
\text { frequency /U/ }\end{array}$ \\
\hline 1 & 2 & 3 & 4 & 5 & 6 \\
\hline \multicolumn{7}{|c|}{ Air-seasoned } \\
\hline $\mathbf{1}$ & $\mathbf{1 0 6}$ & $\mathbf{2 3}$ & $\mathbf{1 . 5} \mathbf{2 . 5}$ & $>\mathbf{2 0}$ & $\mathbf{2 . 1}$ \\
\hline 2 & 200 & 36 & $1.5 ; 2.5$ & 12 & 2.7 \\
\hline 3 & 226 & 40 & 2.5 & 7.4 & 3.5 \\
\hline 4 & 220 & 38 & 2.5 & 8.5 & 3.7 \\
\hline 5 & 240 & 44 & 2.5 & 5.5 & 3.8 \\
\hline 6 & 230 & 63 & 1.5 & 1.9 & 4.1 \\
\hline $\mathbf{7}$ & $\mathbf{2 1 0}$ & $\mathbf{3 8}$ & $\mathbf{2 . 5}$ & $\mathbf{9 . 5}$ & $\mathbf{3 . 6}$ \\
\hline 8 & 270 & 51 & $1.4-2.6$ & 9.5 & 2.6 \\
\hline 9 & 330 & 63 & $1.4-2.6$ & 10 & 2.6 \\
\hline $\mathbf{1 0}$ & 420 & 79 & $1.4-2.6$ & 10.5 & 2.6 \\
\hline
\end{tabular}


The accelerograms (Fig 4) have been obtained with the use of L.I. Ratnikova's program [9] by calculation of motions on the surface and in interior points and with calculated and experimental frequency characteristics of water-saturated layers.

The peak accelerations of solid rocks for horizontal components do not exceed $110 \mathrm{~cm} / \mathrm{s}^{2}$ (Fig. 4A; Table $4 \mathrm{M}-1$ ). It corresponds to reference seismic effect on the rocks of the area equal to 7 units on the intensity scale. The acceleration spectrum (Fig. 4B) has the maximum (at level 0.5) in frequency interval 1-5.5 Hz. Major maximums fall within frequencies 1.5 and $2.5 \mathrm{~Hz}$ and spectral densities on them range up to $22 \mathrm{~cm} / \mathrm{s}(23 \mathrm{~cm} / \mathrm{s}$ - for component EW).

For the reference model represented by average soils (Table 4, model No. 7), the peak acceleration may be as much as $210 \mathrm{~cm} / \mathrm{s}^{2}$ that is to 8 -unit intensity effect corresponding to initial seismicity of the area. For succeeding calculations we have used an initial accelerogram, synthesized for rocky grounds, as a less distorted by near-surface heterogeneities. To make such calculations, seismic models have been constructed to solid rocks taken as reference.

Design parameters of the reference seismic effects are somewhat adjusted to scale of 7-unit intensity for rock foundation and to that of 8-unit intensity for average soils. Nevertheless, they are obtained for real seismic events (see Section 1) corresponding to major potential earthquake source zones for Erdenet town and will correspond to large earthquakes in peak accelerations and frequency content. Besides, scaling provides a more real calculation assessment of the variation in frequency and amplitude content of reference seismic motions of the upper ground layers for the area investigated.

For models No. 2-6 (air-seasoned grounds), the calculation data are summarized in Table 4 and shown in Figure 4 for model No. 6 . For the thickness of loose deposits varying from 5-10 to $50 \mathrm{~m}$, the acceleration of motions varies from 200 to $240 \mathrm{~cm} / \mathrm{s}^{2}$ and is somewhat lower at the maximum thickness. Maximums of the spectrums behave more dynamic with thickening and increase respectively from 36 to $63 \mathrm{~cm} / \mathrm{s}$. The maximums redistribution also occurs; they are somewhat displaced to low frequencies with thickening.

The calculation of seismic effects for partially or strongly water-saturated loose grounds has been made for 3 models, No. 8, 9 and 10 in case of the water plane rising respectively by 5,3 and $0 \mathrm{~m}$ from the surface. This calculation technique needs more development and will be improved later on as well as the previous one. The calculations have been made on the assumption that all motion energy is taken by elastic deformations. Used here is the approach considering increase in strength of motions of the water-saturated ground layer with respect to the waterunsaturated one, through calculation of experimental frequency characteristics [9]. Under this approach, the accelerations for the constructed models are respectively 270,330 and $420 \mathrm{~cm} / \mathrm{s}^{2}$, and the maximum of the spectrum ranges from 51 to 79 $\mathrm{cm} / \mathrm{s}$. Major maximums of the acceleration spectra are on frequencies from 1 to 5 $\mathrm{Hz}$ (Fig. 4A, model No. 10). 
Another important characteristic of seismic effects is the variation in strength of seismic motions of a loose ground layer with the baseband for the models constructed. Figure 4B is a pictorial rendition of frequency characteristics (models No. 1, No. 6 and No. 10). Their basic parameters, maximum increasing of $/ \mathrm{U} /$ and frequency of major maximums are summarized in Table 4.

The frequency of major maximum decreases as thickness of loose deposits increases. Hence, it makes $9.5 \mathrm{~Hz}$ (model No. 7) for a 10-m thick average soil layer and $1.9 \mathrm{~Hz}$ for $50-\mathrm{m}$ thick layer of water-unsaturated soil (Fig. 4C, model No. 6). Maximum increases of an original signal on the same frequencies with regard to double reflection are respectively 3.6 and 4.1 . The range of variation of the examined parameters of the frequency characteristics for models No. 2-7 (Fig. 4C, Table 4) makes $1.9-12 \mathrm{~Hz}$ for frequencies and 4.1-2.7 for amplifications.

At this stage in our research of water-saturated soils, we have analyzed the layers within about $10 \mathrm{~m}$. Because of this, the variations of the basic parameters of frequency characteristics for three models are insignificant and fall on rather high frequencies close to $10 \mathrm{~Hz}$ (Table 4).

An increase in strength of motions for the constructed models at resonance frequencies affects the variation in the level of original signal spectrum at the same frequencies (see Fig. 4). Generally, an increase in acceleration of motions on accelerograms is due to the variation in thickness and acoustic impedance of soil layers, seismic wave attenuation, emergent angle, and other subsurface characteristics on the way of initial seismic motions.

\section{Conclusion}

Seismic zoning of the area of Erdenet town has been started with identifying of seismogenic zones and proving their potential seismic hazard. Neo- and seismotectonic investigations of past years made it possible to recognize geodynamic types and corresponding seismogenic zones on the investigated area. Presented are three types of neotectonic structures with magnitude $>$ 7.0. The first approximation analysis shows the ranges in which large earthquake parameters are variable for the identified potential earthquake source zones. The town is located in an 8-unit seismic intensity area. The recurrence interval for 8-unit intensity earthquakes on the area of the town is once every thousand years. It is pointed out that the basic parameters adopted for large earthquakes and large earthquake recurrence can be defined later on.

The analysis has been made on seismic properties of soils of the area of the town and seismic probability models have been constructed. An original signal has been set corresponding to initial seismicity of Erdenet town. On this basis we have made calculations of seismic hazard in intensity units, accelerograms, peak accelerations of ground motions, dominant period of motions in case of a large earthquake, and resonance frequencies of an unconsolidated unit. Based on these 
characteristics for ten seismic models, covering most of the range of soil conditions of the area of the town, the first approximation zoning of its seismic risk is possible.

Technically, the stages of Erdenet town case study can serve as a basis for seismic zoning of the areas of interest that are adjacent to the Mongolia-Siberian region. 
A

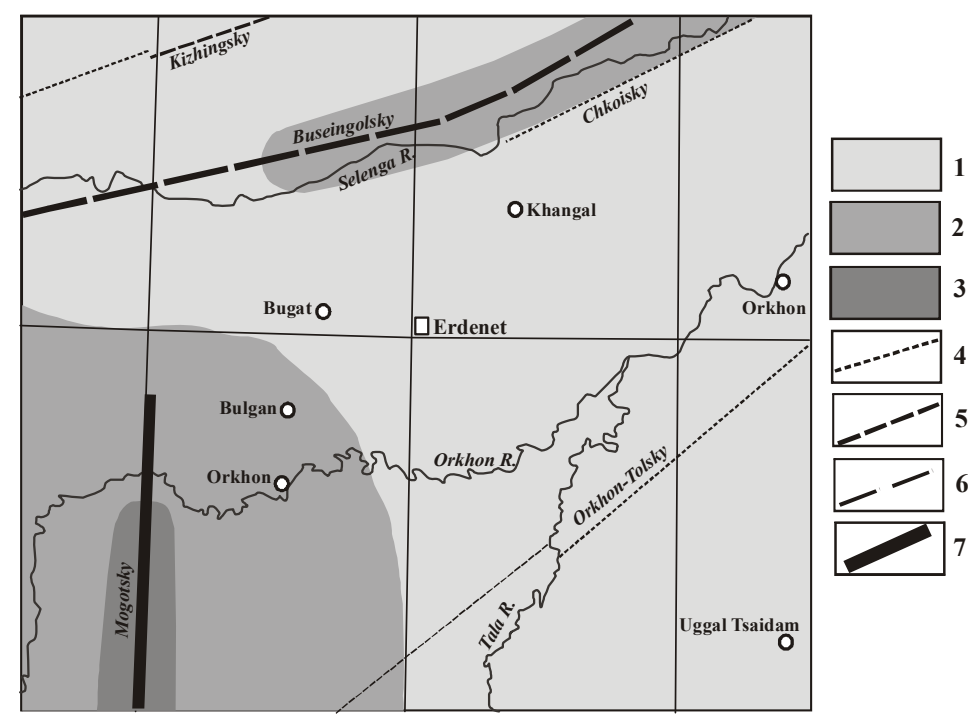

B

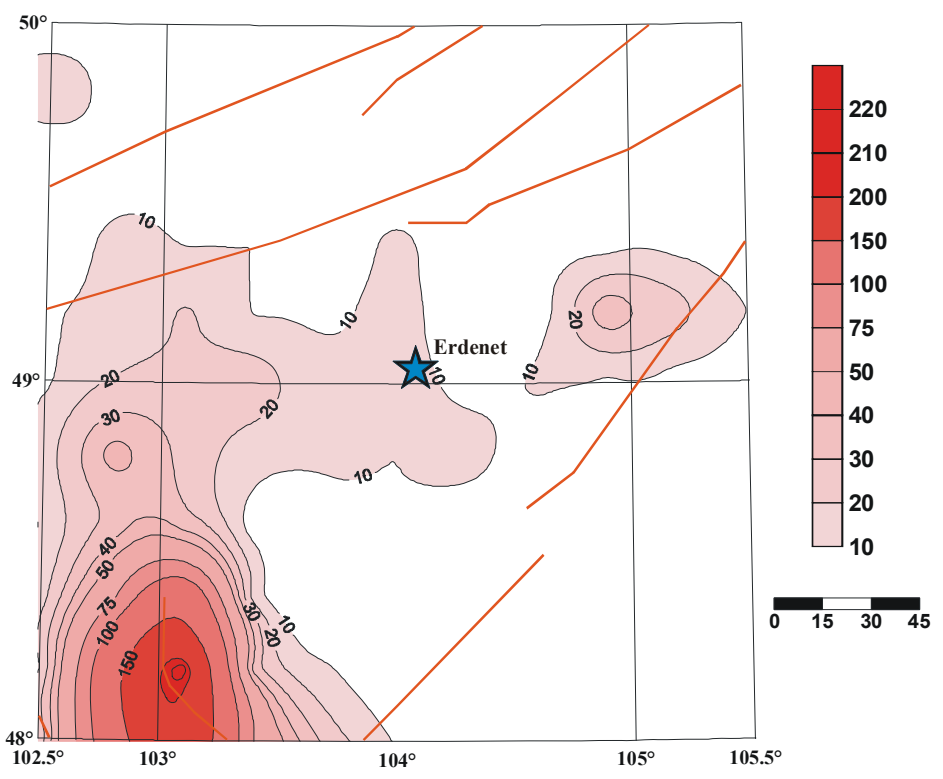

Fig. 1. Seismotectonics near Erdenet town.

A - Map of potential earthquake source zones and seismic microzoning: 1-3 seismic areas (1-8 intensity units, $2-9$ intensity units, 3 - more than 9 intensity units); 4-7 - potential earthquake source zones (4 - Md"6.0, 5 - M=6.0-6.5, 6 - M=7.1-7.5, 7 $M=7.6-7.9)$.

B - Map of earthquake epicenters density. 
A

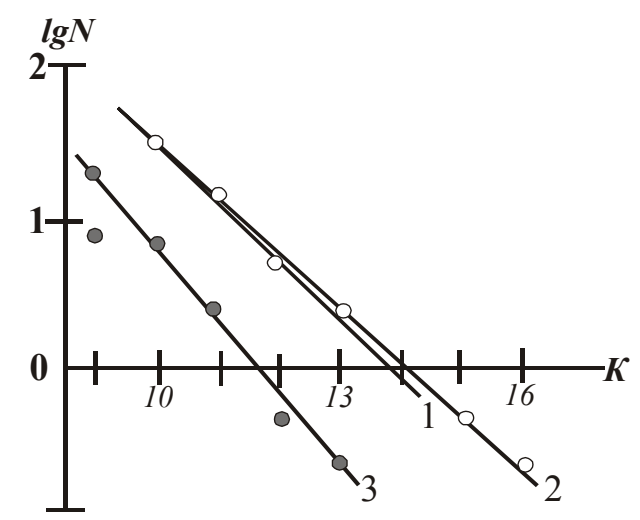

$\mathrm{C}$

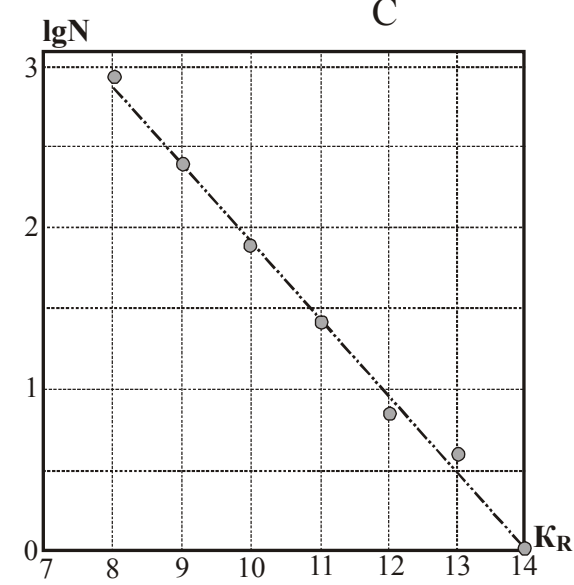

B

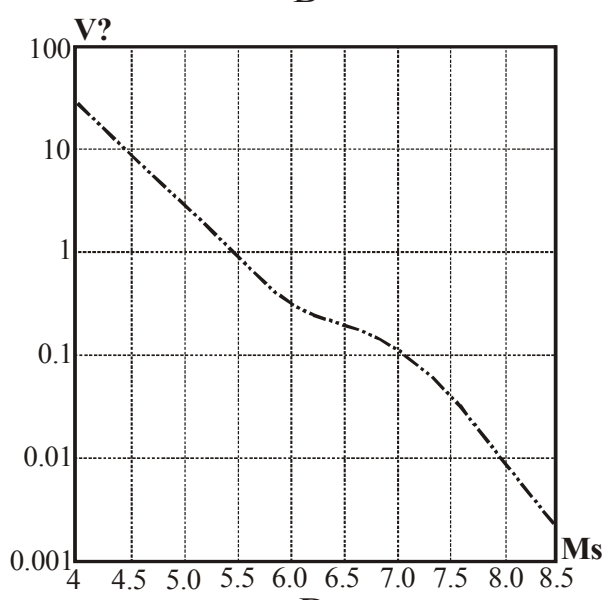

D

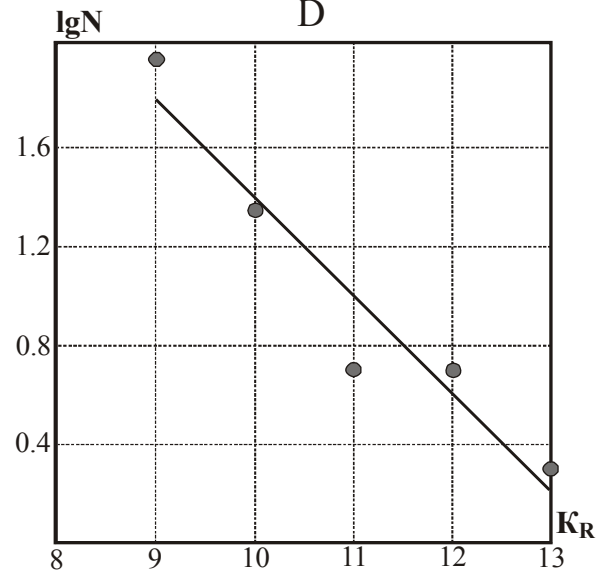

Fig. 2. Seismic setting near Erdenet town.

A - Recurrence curves for the Orkhon-Tuul area: 1 ( $K=9-13)$ and 2 ( $K=9-16)-$ use has been made of all 1964-1968 earthquakes with regard to the aftershocks of the 1967 Mogod earthquake; recurrence curve traced for 1969-1978.

B - Recurrence curve of an annual number of earthquakes with Me" 4.0 for the Altai-Sayan-Baikal region.

C - Recurrence curve of $K_{R}$ e"8 earthquakes over the period from 1968 to 2002.

D - Recurrence curve of $K_{R} e^{\prime \prime} 8$ earthquakes over the period from 1978 to 2002. 


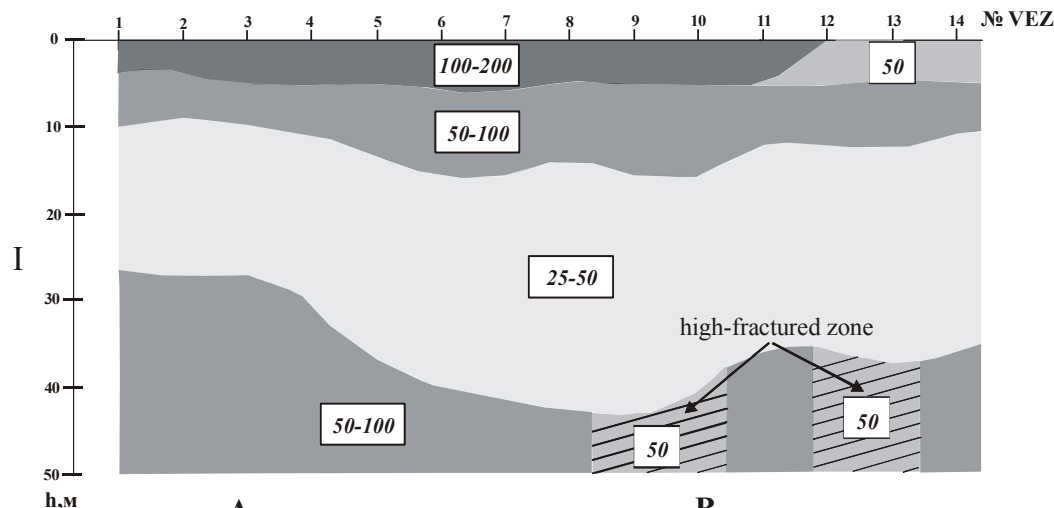

A

B

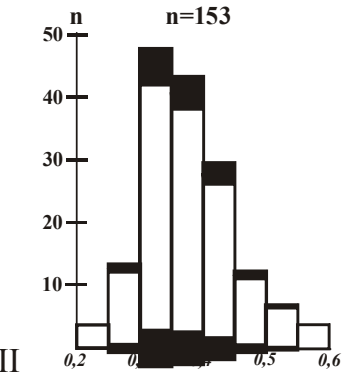

$\mathrm{n}=\mathbf{1 3 8}$

II

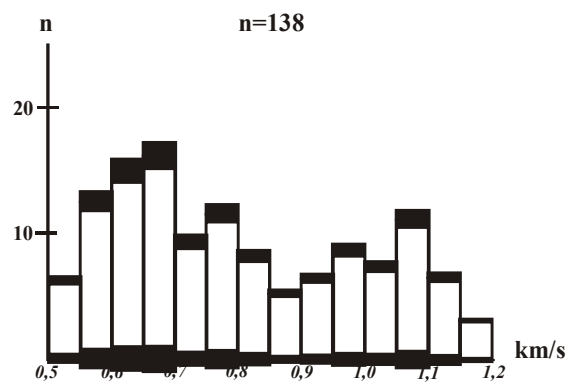

C

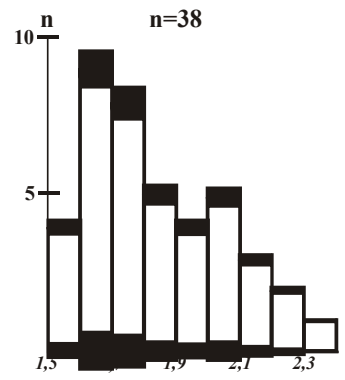

D

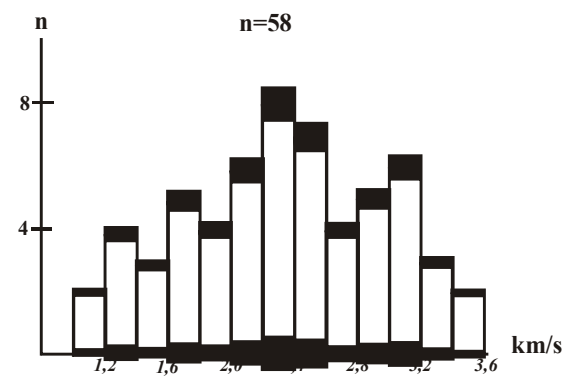

Fig. 3. Physical properties of the rocks near Erdenet town.

I - Geological-geophysical model on the "glord-prombaza" site: 1 - resistance scale; 2 - electric resistances in $\mathrm{Ohm}^{*} \mathrm{~m}$; high-fractured zones.

II - Histograms of longitudinal wave velocities: A - seasonal-frozen grounds; B loose grounds, air-seasoned; C - loose grounds, water-saturated; D - solid rocks. 
A
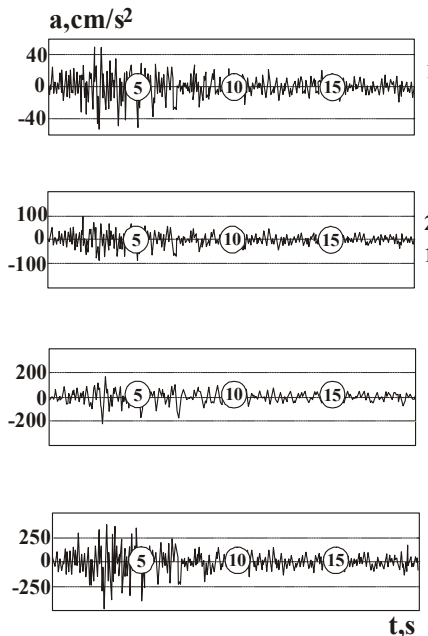

B

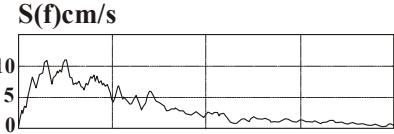

model № 1

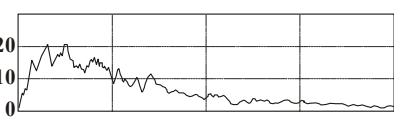

model №6

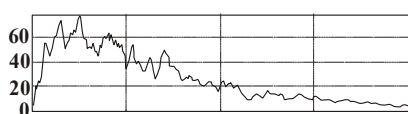

model №10
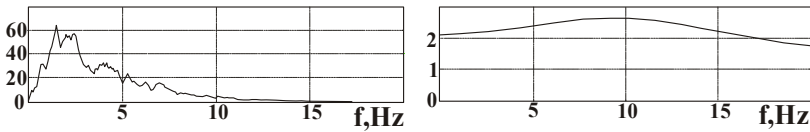

Fig. 4. Accelerograms (A), spectra (B) and frequency characteristics (C) for original signal and models 1,6 and 11 . 


\section{References}

1. Deep structure and geodynamics of the Mongolia-Siberian region. (1995). Nauka, Novosibirsk, 185 pp. (in Russian).

2. Dzurik, V.I., Drennov, A.F., Ivanov, F.I. \& Potapov, V.A. (1986). - Seismic properties of rocky grounds. - Nauka, Novosibirsk, 130 pp. (in Russian).

3. Dzhurik, V.I., Dugarmaa, T., Batsaikhan, Ts., Serebrennikov, S.P. \& Drennov, A.F. (2004). - Technique of seismic risk mapping for the territories of economic development of Mongolia. - Proceedings of Mongolian Academy of Sciences, 16-29.

4. Dzhurik, V.I., Dugarmaa, T. \& Potapov, V.A. (1998). - Seismic microzoning of aimak centers in Mongolia. - AMS, Ulaanbaatar, 248 pp. (in Russian).

5. Dzhurik, V.I., Serebrennikov, S.P., Batsaikhan, Ts., Yushkin, V.I., Eskin, A.Yu. \& Drennov, A.F. (2005). - Reflection of major subsurface fault zones in geophysical fields. - XXXVII Tectonic Conference, Moscow, 2, 202-205 (in Russian).

6. Earthquakes and foundations of seismic zoning of Mongolia. (1985). Nauka, Moscow, 224 pp. (in Russian).

7. General Seismic Zoning Map of Russian Federation. Scale 1:8000000. Explanatory note and list of towns and settlements located in seismic areas. (1999). - Ministry of Science and Technologies of the Russian Federation, Joint Institute of Earth Physics named after O.Yu. Schmidt, Moscow. 57 pp. (in Russian).

8. Lithosphere of Central Asia. (1996). - Novosibirsk, Nauka, 238 pp. (in Russian).

9. Evaluation of soil conditions affecting seismic hazard. (1988). - Seismic microzoning guide. - Nauka, Moscow, 300 pp. (in Russian).

10. Medvedev, S.V. (1962). - Engineering seismology. - Gosstroiizdat, Moscow, 260 pp. (in Russian).

11. Seismic microzoning guidelines in engineering survey for building. (1986). - Gosstroi SSSR, Moscow, 62 pp. (in Russian).

12. Seismic zoning of the East Siberia and its geological-geophysical framework. (1977). - Novosibirsk, Nauka, 303 pp. (in Russian).

13. Seismic zoning in North Mongolia. (1980). - Nauka, Moscow, 179 pp. (in Russian).

14. Seismic survey. Guide for a geophysicist (1981). - Nedra, Moscow, 462 pp. (in Russian).

15. Seismic microzoning. (1984). - Nauka, Moscow, 224 pp. (in Russian).

16. Construction norms and regulations. CNaR-11-7-81. Building in seismic areas (Chapter 7). (1982). - Gosstroi SSSR, Moscow, 80 pp. (in Russian). 
17. Ulomov, V.I. \& Shumilina, L.S. (1998). - A suite of new general seismic zoning maps of Russian Federation. - Earthquake engineering, 4, 30-34 (in Russian).

18. Electric survey. Guide for a geophysicist. (1981). - Nedra, Moscow, 516 pp. (in Russian). 